\title{
PREDICTING OF RESPIRATORY TRACT PATHOLOGY RISK FACTORS AND THE NURSES' KNOWLEDGE IN NOSOCOMIAL PNEUMONIA PREVENTING
}

Predicting of respiratory tract pathology risk factors and the nurses' knowledge in nosocomial pneumonia preventing

I. Ya. Krynytska, M. I. Marushchak, L. P. Mazur, T. I. Dzetsiukh, A. O. Hrad, H. H. Habor

I. Horbachevsky Ternopil National Medical University

e-mail: krynytska@tdmu.edu.ua

Summary. For a more complete understanding of the main risk factors for nosocomial pneumonias, as well as optimizing their prevention, it is important to evaluate not only individual measures to prevent nosocomial pneumonia, but also the determination of the nurses' knowledge, which are necessary for the adequate conducting of these activities, justifies the relevance of this study.

The aim of the study - to analyze the prevalence of nosocomial pneumonias (NP) in surgical and therapeutic departments and determine the nurses' knowledge on the problem of preventing hospital pneumonia.

Materials and Methods. In order to determine the nurses' level of knowledge on the problems of preventing nosocomial pneumonia, a questionnaire was developed and applied, which included 20 questions with answers.

Results. The prevalence of hospital pneumonia in the departments of the therapeutic and surgical profiles is high. The incidence of NP in the surgical department is predominant in males, among the risk factors in which tobacco smoking prevails. In females with NP, the main etiological factors include poor nutrition and obesity. Comparing the level of nurses' knowledge in therapeutic and surgical departments it was found that nurses of surgical department have shown better knowledge of NP identifying and epidemiology. Nursing stuff of both profiles has poor knowledge about pathogens of NP. The most problematic for nurses of both departments is the issue of preventing NP in case of various surgical interventions during preoperative period.

Conclusion. The results of the surveys with this questionnaire can be used to focus educational programs on NP prevention.

Key words: nosocomial pneumonias; knowledge; nurses.

\section{INTRODUCTION}

Nosocomial infections, also called "hospital-acquired infections", are infections acquired during hos-
Прогнозування фракторів ризику патології системи дихання та рівень знань медичних сестер щодо профрілактики нозокоміальної пневмонії

І. Я. Криницька, М. І. Марущак, Л. П. Мазур, T. І. Дзецюх, А. О. Град, Г. Г. Габор

Тернопільський національний медичний університет імені І. Я. Горбачевського МОЗ України

Резюме. Для глибшого розуміння основних фракторів ризику нозокоміальних пневмоній, а також для оптимізації їх профрілактики важливо оцінювати не тільки окремі заходи щодо запобігання нозокоміальної пневмонії, але й знання медичних сестер, необхідних для адекватного проведення цих заходів, що обірунтовує актуальність цього дослідження.

Мета дослідження - проаналізувати поширеність нозокоміальних пневмоній (НП) у хірургічних та терапевтичних відділеннях лікарні й визначити знання медичних сестер щодо проблеми профрілактики госпітальної пневмонії.

Матеріали і методи. Для визначення рівня знань медичних сестер з проблем профрілактики нозокоміальної пневмонії було розроблено та застосовано анкету, яка включала 20 запитань із відповідями.

Результати. Поширеність госпітальної пневмонії у відділеннях терапевтичного та хірургічного профрілів висока. Захворюваність на НП у хірургічному відділенні переважає серед чоловіків, де основним фрактором ризику є тютюнокуріння. У жінок із НП до основних етіологічних чинників відносять нераціональне харчування та ожиріння. Порівнюючи рівень знань медичних сестер у терапевтичних та хірургічних відділеннях, було встановлено, що медсестри хірургічного відділення показали кращі знання щодо виявлення НП та епідеміології. Медичні сестри обох профрілів мають низькі знання щодо збудників хвороби НП. Найпроблемнішим для них $є$ питання запобігання НП при різних хірургічних втручаннях у передопераційному періоді.

Висновок. Результати опитування за допомогою запропонованої анкети можуть бути використані для орієнтації освітніх програм для профрілактики НП.

Ключові слова: нозокоміальна пневмонія; знання; медсестри.

pital care which are not present or incubating at admission [1]. Recently, a new term, "healthcare associated infections" (HAIs) is used for the type of infections 
caused by prolonged hospital stay [2, 3]. They result in high morbidity and mortality, extended hospitalization, greater use of antibiotics, and increased costs.

Studies indicated that nosocomial infections occurred in 5-10\% of all hospitalizations in Europe and North America and in more than $40 \%$ of hospitalizations in parts of Asia, Latin America, and sub-Saharan Africa [4]. The risk of health-careassociated infection was estimated to be two to twenty times higher in developing countries than that of resource-rich countries with the percentage of infected patients exceeding $25 \%$. The highest frequencies of nosocomial infections reported from hospitals in the Eastern Mediterranean and South East Asia Regions are $11.8 \%$ and $10.0 \%$ respectively [5]. About $75 \%$ of the burden of HAls is present in developing countries [6].

National Healthcare Safety Network with Center for Disease Control for surveillance has classified nosocomial infection sites into 13 types, with 50 infection sites, which are specific on the basis of biological and clinical criteria. The sites which are common include urinary tract infections, surgical and soft tissue infections, gastroenteritis, meningitis and respiratory infections [3]. According to literature data, nosocomial pneumonia (NP) accounts for about $15 \%$ of all nosocomial infections and is associated with the highest mortality rate - 20-33 \% [7]. According to Kim Lam Soh, NP has the highest mortality rate ranging from $13 \%$ to over $50 \%$ [8]. The most dangerous complication of NP is acute lung injury, which remains a major cause of acute respiratory failure and death of patients [9].

Hospital acquired infections usually only receive public attention when there are epidemics. Although hidden from public attention, HAls are a very real endemic and on-going problem. Maintaining a safe and hygienic work environment prevents the spread of HAls. An effective infection control program in an acute-care hospital must include trained nursing staff, dedicated physicians in infection control, microbiological support, and data management support [5].

For a more complete understanding of the main risk factors for nosocomial pneumonias, as well as optimizing their prevention, it is important to evaluate not only individual measures to prevent nosocomial pneumonia, but also the determination of the nurses' knowledge, which are necessary for the adequate conducting of these activities, justifies the relevance of this study.

The aim of the study - to analyze the prevalence of nosocomial pneumonias in surgical and therapeutic departments and determine the nurses' knowledge on the problem of preventing nosocomial pneumonia.

\section{MATERIALS AND METHODS}

During the 2013-2015 years, a retrospective analysis of 900 case histories in the surgical and therapeutic departments of the Ternopil University Hospital was conducted.

The analysis of risk factors was carried out by interviewing 26 patients who were on inpatient treatment in the surgical and pulmonary (therapeutic) department of the Ternopil University Hospital. Among all NP patients, 18 patients were men (62.1\%) and 8 - women (37.9\%).

It should be noted that in the therapeutic department, both the male and female cases of nosocomial pneumonia were equally encountered, whereas in the surgical department the incidence of NP was dominant in men. The mean age was older among the patients of the therapeutic profile $-(64.3 \pm 4.8)$ years, in the group of patients of the surgical department the mean age was younger - $(52.6 \pm 5.8)$ years. This is due to the fact that a significant proportion of patients entering the surgical department have an urgent pathology, which does not depend on age, and often the patients enter the therapeutic departments in the planned order and in old age.

In order to determine the nurses' level of knowledge on the problems of preventing nosocomial pneumonia, a questionnaire was developed and applied, which included 20 questions with answers (appendix A).

Thus, we determined the level of knowledge not only in the field of prevention, but also knowledge about the etiology and pathogenesis of nosocomial diseases. The answers were estimated as follows: the correct answer -1 point, the wrong answer -0 . In case when it is necessary to give 2 answers, and only 1 was present -0.67 points; one correct, and the second incorrect -0.33 points; when it is necessary to give 3 answers, for each correct we add 0.35 points, for each incorrect - subtract 0.15 points.

Sample size calculation and Statistical analysis. All of the results were processed using the software package Statistica 6.1 for Windows. The mean (M) and standard error of the mean (SEM) were deduced. For data with normal distribution, intergroup comparisons were performed using Student's t-test, in other cases using the Mana-Whitney U-criterion. $P$ value less than 0.05 was considered significant.

\section{RESULTS AND DISCUSSION}

Archival data (2013-2015) of studied case histories were analyzed for determination the main etiological factors and prevalence of the respiratory pathology in the anamnesis of nosocomial pneumonia. Identifying the main etiological factors, it was established that male patients with NP practically all smoked (88.9\%), two of them - drank alcohol, in 2 
patients the body mass index was more than 30 , in 5 patients - an unhealthy diet was noted. The obtained data indicate that smoking is the main risk factor for male patients, and other factors increase the immunodeficiency, which is the basis of infectious invasion. It should be noted that almost all smoking patients were combined with one or more factors and no drug history was registered in any medical history. In women with NP, the main etiological factors included poor nutrition in $25 \%$ and, conversely, obesity - in $25 \%$.

Characterizing the investigated groups, it was found that NP in patients of the surgical department most often appeared after surgery with preliminary antibiotic therapy, while patients had a history of chronic bronchitis, chronic obstructive pulmonary disease (COPD), and pneumonia (Table 1). Among antibiotics, a group of cephalosporins, in particular ceftriaxone, was used most often. The main operations were laparotomy, appendectomy and hernioplasty.

In patients of therapeutic department, the prevalence of the pathology of the respiratory organs was as follows: most often there was pneumonia in the anamnesis, COPD and chronic bronchitis were equally identified.

Comparing the prevalence of the pathology of the respiratory organs in the history of NP, it can be argued that pneumonia is a risk factor for nosocomial pneumonia in patients with a predominantly therapeutic profile, whereas chronic bronchitis and COPD are almost equally detected in patients of the therapeutic and surgical departments.

The next stage of our work was to determine the nurses' knowledge about the prevention of nosocomial pneumonia with the help of questionnaires. The questions were divided into several conditional blocks: block 1 - "Definition and Epidemiology" (5 questions), block 2 - "Etiology, Pathogenesis, Risk Factors" (6 questions), block 3 - "Infection Control and Prevention of NP" (9 questions). The analysis of the answers was carried out both for individual questions and for subject blocks, and also for the whole questionnaire in general.

When analyzing the questionnaire data of 14 medical staff questionnaires of the therapeutic department, it was found that, with an average level of correct responses of $68.5 \%$, the knowledge of the medical nurse of the therapeutic profile differed somewhat in questions in blocks, with the slightest knowledge found in the thematic block "Infection Control and Prevention of NP ". The best knowledge of the medical staff of the therapeutic department was shown from the section "Definition and Epidemiology" of the NP.

Almost equally low were the results in the block of questions "Etiology, Pathogenesis, Risk Factors" and "Infection Control and Prevention of NP," which indicates insufficient training of specialists in this direction.

Analyzing the individual answers to the questions of block 1, it was found that the most problematic were the answers to questions 4 and 5 on the prevalence and mortality rate from nosocomial pneumonia $(p<0.01)$. The best nurses of therapeutic department responded to question 1 about synonyms of the term "hospital" in $85.7 \%$ of cases (Fig. 1, A).

Analyzing the individual answers to the questions of block 2, it was found that the most problematic were the answers to questions 6 and 7 on the most characteristic pathogens of nosocomial pneumonia $(p<0.001)$. At the same time, it was found that 5 nurses answered question 6 , and only 3 nurses answered to number 7 , which indicates insufficient training of specialists in the field of etiology of the NP. The nurses of the therapeutic department are the best aware of the risk factors for developing nosocomial pneumonia, since 10 nurses gave a complete answer to question 8, and 12 to question 9 (Fig. 1, B).

Analyzing the individual answers to the questions of block 3, an average level of knowledge on infection control and prevention of nosocomial pneumonia has been established. The most problematic for nurses turned out to be question 13 (not a single full correct answer) about measures to prevent nosocomial infection and question 17 on sanitation of the oral cavity in cardiac surgery in the preoperative period (8 medical workers gave the right answer). The average level of knowledge in this bloc ranged from $46.7 \%$ to $76.6 \%$. The best nurses in the therapeutic department are aware of the rules for hand sanitizer treatment, since 7 nurses gave a complete answer to question 19, and the rest - only 1 correct answer from two correct ones (Fig. 2, A)

Summarizing the obtained data, it was established that despite a sufficient level of knowledge based on

Table 1. Prevalence of the respiratory pathology in the anamnesis of nosocomial pneumonia

\begin{tabular}{l|c|c|c}
\hline \multicolumn{1}{c|}{ Indices } & Surgical department & Therapeutic department & $\begin{array}{c}\text { Difference between } \\
\text { groups }\end{array}$ \\
\hline Pneumonia & $8(38.1 \%)$ & $5(62.5 \%)$ & $\mathrm{p}<0.05$ \\
\hline COPD & $7(33.3 \%)$ & $3(37.5 \%)$ & $\mathrm{p}>0.05$ \\
\hline Chronic bronchitis & $6(28.3 \%)$ & $2(25.0 \%)$ & $\mathrm{p}>0.05$ \\
\hline Prior antibiotic therapy & $16(76.2 \%)$ & $3(37.5 \%)$ & $\mathrm{p}<0.05$ \\
\hline Surgery & $14(66.7 \%)$ & - & $\mathrm{p}<0.001$ \\
\hline
\end{tabular}



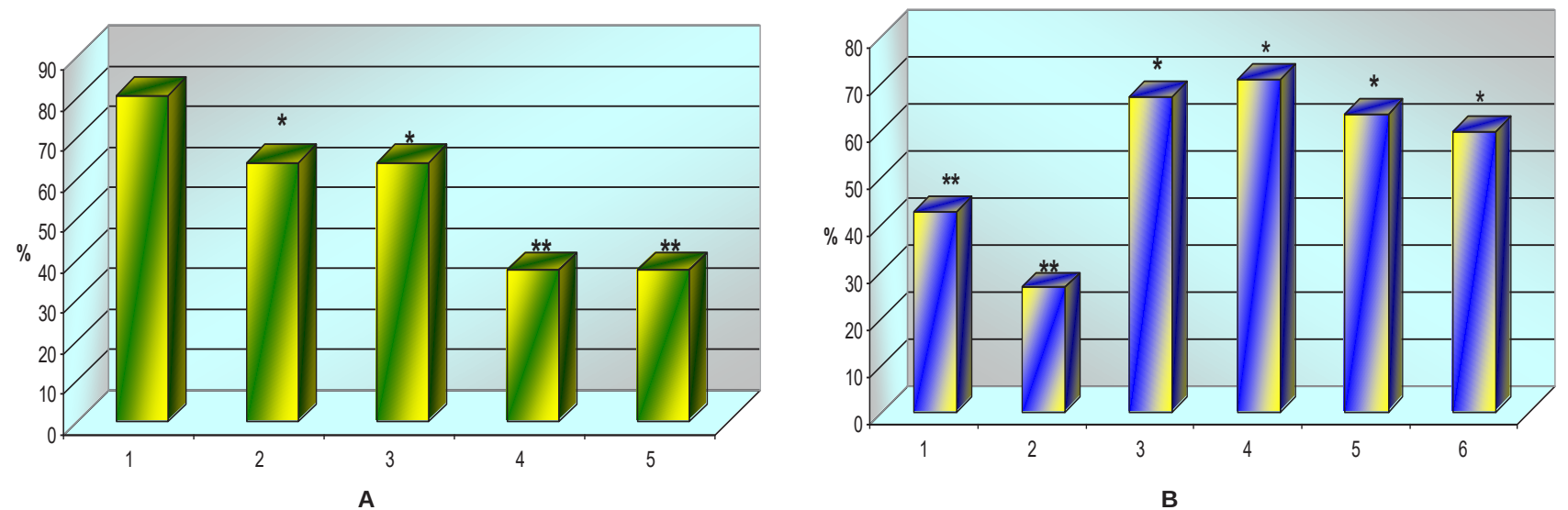

Figure 1. Percentage of correct responses of the initial knowledge level of block-1 "Definition and Epidemiology" (A) and block-2 "Etiology, Pathogenesis and Risk Factors" (B) of therapeutic stuff nurses.

Note: * - the reliability of the differences between the control and the responses of nurses to individual questions $\left({ }^{\star}-\mathrm{p}<0.05,{ }^{*}-\mathrm{p}<0.01\right)$.

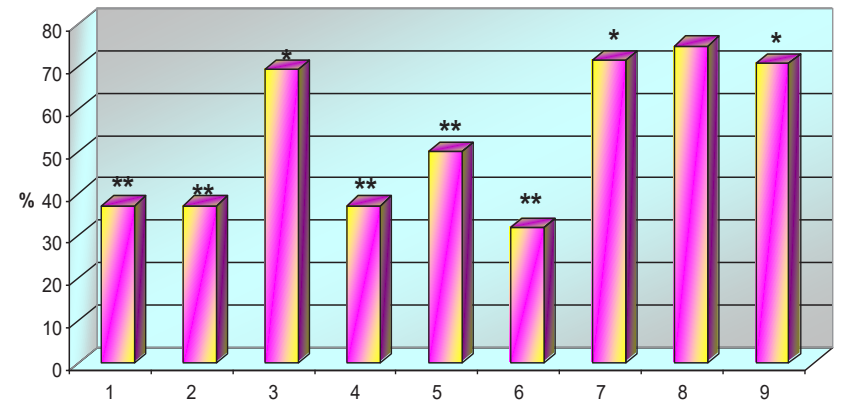

A

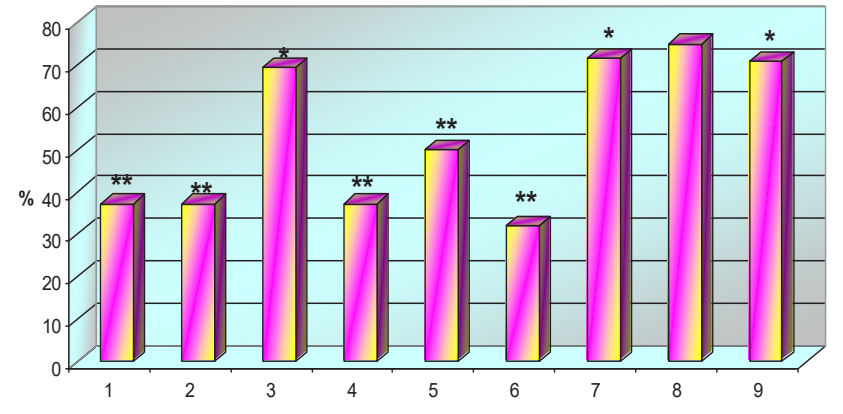

B

Figure 2. Percentage of correct responses of the initial knowledge level of block-3 "Infection Control and Prevention of Nosocomial Pneumonia" of therapeutic (A) and surgical (B) stuff nurses.

Note: * - the reliability of the differences between the control and the responses of nurses to individual questions $\left({ }^{\star}-p<0.05,{ }^{\star \star}-p<0.01\right)$.

the results of the questionnaire $(68.5 \%$ of the correct answers), a number of questions the nurses know extremely poorly. This concerns the prevalence and lethality of NP, characteristic pathogens of NP, as well as measures to prevent nosocomial infections. The received data testify to the necessity of carrying out educational measures to improve the level of knowledge of the therapeutic nurses in the pathology under study.

When analyzing the data of the initial questionnaire, 14 questionnaires of the medical staff of the surgical department showed that, with an average level of correct answers of $67.7 \%$, the knowledge of the surgical nurses was somewhat different in questions in the blocks, with the slightest knowledge found in the thematic block "Infection Control and Prevention of NP". The best knowledge of the medical staff of the therapeutic department was shown in the "Definition and Epidemiology" section of the NP (79.2\% of correct answers). Almost the same results were in the block of questions "Etiology, Pathogenesis, Risk Factors" and "Infection Control and Prevention of NP", which indicates the average training of specialists in this direction.

Analyzing the individual answers to the questions of block 1, it was found that the most problematic were the answers to questions 4 and 5 on the prevalence and mortality rate from nosocomial pneumonia, to which only $37.3 \%$ of the medical staff answered correctly $(p<0.01)$. The nurses of the surgical department are best guided in determining the length of nosocomial pneumonia, since $80.4 \%$ of cases answered question 1 about synonyms for the term "hospital pneumonia" (Fig. 3, A).

Analyzing the individual answers to the questions of block 2, it was found that the most problematic were the answers to questions 6 and 7 regarding the pathogens of NP with the highest risk of death for the patient (question 8 was answered correctly by 8 nurses, question No. 7 - only by 5 nurses) ( $p<0.001)$. At the same time, it was found that the nurses of the surgical department are best aware of the risk factors for the development of nosocomial pneumonia, since 8 nurses gave a full answer to question 8, and 10 - to question 9 (Fig. 3, B). 

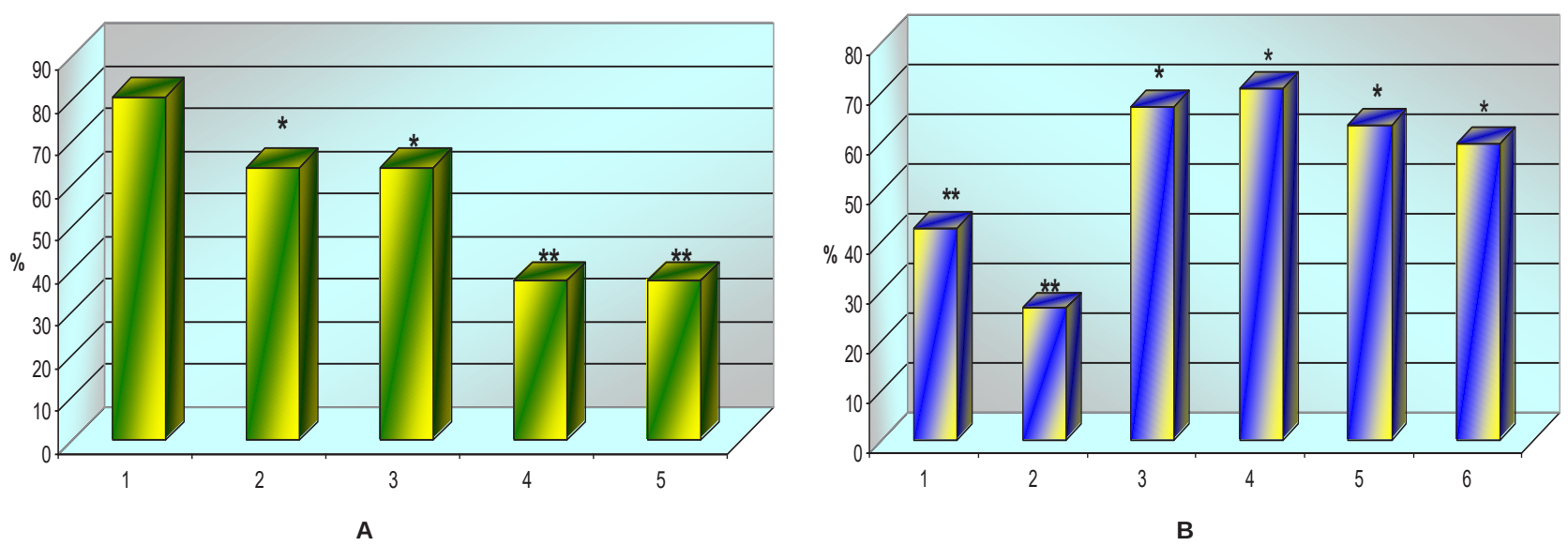

Figure 3. Percentage of correct responses of the initial knowledge level of block-1 "Definition and Epidemiology" (A) and block 2 "Etiology, Pathogenesis and Risk Factors" (B) of surgical stuff nurses.

Note: * - the reliability of the differences between the control and the responses of nurses to individual questions $\left({ }^{*}-p<0.05,{ }^{* *}-p<0.01\right)$.

Analyzing the individual answers to the questions of block 3 , an average level of knowledge on infection control and prevention of NP has been established. The most problematic for nurses were question 12 about the measures in the arsenal of the nurse in the prevention of NP, question 13 (not a single full correct answer) about the measures for the prevention of nosocomial infection, question 15 the question of measures, which the nurse must perform on the basis of the ward in which the patient with resistant staphylococcus is located, question 16 (one complete correct answer) on measures of infection control to prevent the spread of medical staff NP and question 17 on the sanitation of the oral cavity in cardiac surgery in the preoperative period. The average level of knowledge in this block ranged from $32.0 \%$ to $71.0 \%$. The best nurses of the surgical department are aware of the disinfecting agents and the algorithms for the use of personal respiratory protective equipment (Fig. 2, B).

HAls are an increasingly recognized problem. The number of people who are sickened or die and the financial impact from HAls are unacceptably high. Healthcare delivery is complex and dynamic. New devices and invasive procedures are developed and introduced at an extraordinary rate, creating the need for prospective assessment of hazards associated with new technology.

Experts in healthcare epidemiology, infectious diseases, and infection prevention should identify and should address potential infections associated with these newer technologies and procedures through collaboration with developers and those who test new devices. In addition, new and emerging pathogens and resistance remain an ongoing threat in all healthcare settings [10].

Nurses should be familiar with practices to prevent the occurrence and spread of HAls, and maintain appropriate practices for all patients throughout the duration of their hospital stay. According to Kim Lam Soh staff nurses have an important role in preventing NP by decreasing risk factors (Fig. 4), recognizing early symptoms, and assisting in diagnosis [8].

The nurse in charge of a ward is responsible for: maintaining hygiene, consistent with hospital policies and good nursing practice on the ward; monitoring aseptic techniques, including hand washing and use of isolation; reporting promptly to the attending physician any evidence of infection in patients under the nurse's care; initiating patient isolation and ordering culture specimens from any patient showing signs of a communicable disease, when the physician is not immediately available; limiting patient exposure to infections from visitors, hospital staff, other patients, or equipment used for diagnosis or treatment; maintaining a safe and adequate supply of ward equipment, drugs and patient care supplies [1].

Our study showed that problem of nosocomial pneumonia is not paying enough attention, therefore, the prevalence of hospital pneumonia in the departments of the therapeutic (up to $2.0 \%$ ) and surgical (up to $5.3 \%$ ) profiles is high. The incidence of NP in the surgical department is predominant in males, among the risk factors in which tobacco smoking prevails. In females with NP, the main etiological factors include poor nutrition and obesity. Among the pathology of the respiratory system, pneumonia is a risk factor for NP in patients with a predominantly therapeutic profile, whereas chronic bronchitis and chronic obstructive pulmonary disease are almost equally apparent in patients in the therapeutic and surgical departments.

It should be noted that the prevalence of NP in our study in the surgical department coincides with the general statistical data [11]. We did not manage to carry out a statistical analysis of the NP frequency by years because of the small number of patients identified. 


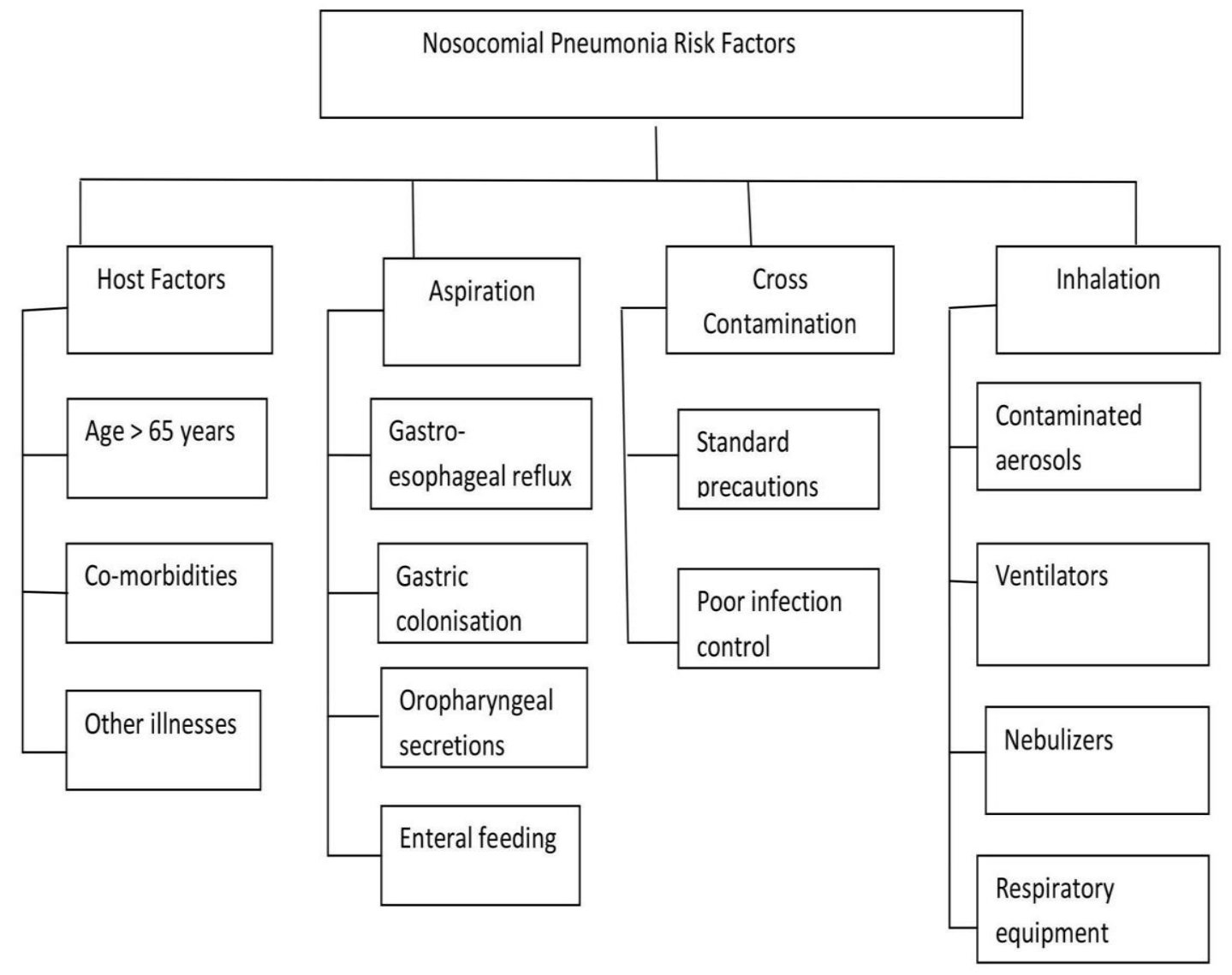

Figure 4. Nosocomial pneumonia risk factors.

Comparing the level of nurses' knowledge in therapeutic and surgical departments it was found that despite in average the similar knowledge, nurses of surgical department, working in Ukraine, showed better knowledge of NP identifying and epidemiology. Nursing stuff of both profiles have poor knowledge about pathogens of nosocomial pneumonia, but greater knowledge about the main risk factors for NP. The most problematic for nurses of both departments is the issue of measures to prevent HAls and methods of preventing NP in case of various surgical interventions during preoperative period.

There is a growing body of literature to inform stuff nurses in preventing NP among patients. Strong evidence indicates that elevating the head of the bed reduces both the frequency and severity of pulmonary aspiration. Regular monitoring of gastric residual in enteral feeding patients is important because persistent high gastric volume predisposes patients to regurgitation and pulmonary aspiration. Other educational topics include the use and monitoring of heat moisture exchanger, how to identify early signs of pneumonia, when culturing is necessary, and the NP risks associated with suctioning. Finally, education and reinforcement about hand washing is vital. As well as the growing body of literature identifying evidenced based nosocomial infection prevention activities, numerous internet sites are available to support infection control learning [8].

Additionally, increasing the average level of knowledge was the first step in successful multifaceted educational programs. Researchers underline the importance of having a continuous training programme for nursing and staff, indicating the need to ensure that all staff work together on the preparation and regular updating of evidence-based clinical and nursing protocols and guidelines [12].

Limitations

1. The study was conducted on small number of staff nurses.

2. The study was conducted for a minimum period.

3. The study was limited to only one area.

\section{CONCLUSIONS}

Our study findings demonstrate that nurses' knowledge about nosocomial pneumonia guidelines is not good, and highlights the need for comprehensive education based on the current recommendations. The results of the surveys with this questionnaire can be used to focus educational programs on nosocomial pneumonia prevention. The questionnaire can also be used before and after educational programs to assess the effect of the programs on nurses' knowledge of interventions to prevent nosocomial pneumonia. 
Appendix A

Questionnaire for determining the level of knowledge of nurses on the prevention of hospital pneumonia

1) The term "hospital" is synonymous with:
A. in-hospital
B. nosocomial
C. outpatient
D. atypical
E. difficult to answer

2) Nosocomial pneumonia is a pneumonia that occurs after:

A. 24 hours after patient's admission into the hospital

B. 48 hours after patient's admission into the hospital

C. 72 hours after patient's admission into the hospital

D. 5 hours after patient's admission into the hospital

E. difficult to answer

3) The incidence of nosocomial pneumonia in surgical departments:
A. $0.02-0.2 \%$
B. $0.5-5 \%$
C. $10-25 \%$
D. difficult to answer

4) The incidence of nosocomial pneumonia in therapeutic departments:
A. $0.02-0.2 \%$
B. $0.5-5 \%$
C. $10-25 \%$
D. difficult to answer

5) Mortality from nosocomial pneumonia is:

A. $1-5 \%$, regardless of the type of pathogen and other factors

B. 1-5\%, depending on the type of pathogen and other factors

C. 5-70\%, regardless of the type of pathogen and other factors

D. 5-70\% depending on the type of pathogen and other factors

E. difficult to answer

6) Indicate the 2 most characteristic groups of pathogens of nosocomial pneumonia:

A. pneumococci, staphylococci

B. Pseudomonas aeruginosa, enterobacteria

C. mycoplasma, chlamydia, legionella

D. Hemophilus rod, fungi of the genus Candida

E. difficult to answer

7) Which pathogen of nosocomial pneumonia will cause the greatest risk of the patient's lethality:
A. Staphylococcus aureus
B. Pseudomonas aeruginosa
C. Legionnaires
D. Klebsiella
E. difficult to answer

8) Which patients belong to the "high risk" group of nosocomial pneumonia development?

A. after surgery

B. with a severe course of the underlying disease, patients on mechanical ventilation
C. with concomitant diseases of the respiratory system, in the history had pneumonia

D. difficult to answer

9) Modified risk factors for nosocomial pneumonia include:
A. duration of mechanical ventilation
B. enteral nutrition
C. use of a nasogastric tube
D. tracheostomy
E. difficult to answer

10) A significant contribution to the pathogenesis of nosocomial pneumonia is made by:
A. depression of the immune system
B. violation of mucociliary clearance of airways
C. presence of pathogens
D. difficult to answer

11) Risk factors for the development of nosocomial pneumonia, which can be eliminated:

A. cross-infection from health care personnel and other patients

B. improper use of antibiotics

C. use of sedatives

D. inadequate disinfection of medical equipment and apparatus

E. difficult to answer

12) Measures in the arsenal of a nurse in the prevention of nosocomial pneumonia include:
A. disposable gloves
B. orders that need to be obeyed
C. bactericidal lamps
D. antibiotic therapy
E. difficult to answer

13) Prevention of nosocomial infection includes:
A. organizational arrangements
B. epidemiological measures
C. scientific and methodical events
D. difficult to answer

14) Indicate the distance to the patient at which the nurse usually needs to wear a mask:
A. less than 1 meter
B. less than 3 meters
C. less than 5 meters
D. the nurse must always be masked
E. difficult to answer

15) Leaving the room, in which there is a patient with resistant staphylococcus, the nurse must:
A. change all outerwear
B. change gown and mask
C. change gown, mask and gloves
D. enough to wash hands
E. difficult to answer

16) The most important measure of infection control to prevent the spread of nosocomial infection by health care personnel is:

A. changing medical clothes, masks

$B$. washing hands after each contact with the patient

C. correct administration of antibiotics

D. sanitizing the premises 
E. difficult to answer

17) For cardiac surgery in the preoperative period, it is necessary to rinse the oral cavity with:

A. $0.12 \%$ chlorhexidine gluconate solution twice daily

B. $0.12 \%$ chlorhexidine gluconate solution once a day

C. Givalex antiseptic twice a day

D. Givalex antiseptic after each meal

E. difficult to answer

18) Which disinfectants are used for washing and treating hands:
A. $70 \%$ ethyl alcohol with $1 \%$ glycerin solution
B. $90 \%$ ethyl alcohol
C. $0.5 \%$ aqueous solution of chlorhexidine gluconate
D. $0.12 \%$ solution of chlorhexidine gluconate
E. difficult to answer

19) How to handle hand sanitizers correctly:

A. before the manipulations associated with possible and obvious damage to the skin and mucous membranes of the patient

\section{REFERENCES}

1. World Health Organization. Prevention of hospitalacquired infections: a practical guide. Geneva, Switzerland: World Health Organization; 2002. Available at: http://www. who.int/csr/resources/publications/whocdscsreph2002.pdf.

2. Brusaferro S, Arnoldo L, Cattani G, Fabbro E, Cookson B, Gallagher R, Hartemann P, Holt J, Kalenic S, Popp W, Privitera G. Harmonizing and supporting infection control training in Europe. Journal of Hospital Infection. 2015;89(4): 351-6. Available at: https://www.ncbi.nlm.nih. gov/pubmed/25777079.

3. Khan HA, Ahmad A, Mehboob R. Nosocomial infections and their control strategies. Asian Pacific Journal of Tropical Biomedicine. 2015;5(7): 509-14. Available at: http://www. sciencedirect.com/science/article/pii/S2221169115000829.

4. Bereket W, Hemalatha K, Getenet B, Wondwossen T, Solomon A, Zeynudin A, Kannan S. Update on bacterial nosocomial infections. Eur Rev Med Pharmacol Sci. 2012;16(8): 1039-44. Available at: http://www.europeanreview.org/wp/wpcontent/uploads/1249.pdf.

5. Shahida SM, Islam A, Dey BR, Islam F, Venkatesh K, Goodman A. Hospital acquired infections in low and middle income countries: root cause analysis and the development of infection control practices in Bangladesh. Open Journal of Obstetrics and Gynecology. 2016;6(01): 28. Available at: http://file.scirp.org/pdf/OJOG_2016012115352918.pdf.

6. Obiero CW, Seale AC, Berkley JA. Empiric treatment of neonatal sepsis in developing countries. The Pediatric Infectious Disease Journal. 2015;34(6): 659-61.
B. before and after manipulations associated with possible and obvious damage to the skin and mucous membranes of the patient

C. before contact with wound dressings and infected wounds

D. before and after contact with wound dressings and infected wounds

E. difficult to answer

20) The rules for the use of personal respiratory protective equipment include the following items:

A. protective medical masks and respirators should be replaced immediately if moistened or contaminated

$B$. if the use of a mask or respirator is not required, they must be removed (they should not be placed on the neck)

C. after touching the mask or respirator, removing or disposing of the mask, immediately handle hand sanitizers

D. difficult to answer

7. Yakovleva O, Ihlchenko A. Hospital pneumonia diagnostics and antibacterial therapy features in patients of neurosurgical department. Ukrainian Neurosurgical Journal. 2012;(3): 43-7.

8. Soh KL, Wilson J, Koziol-McLain J, Soh KG. Critical care nurses' knowledge in preventing nosocomial pneumonia. Australian Journal of Advanced Nursing, The. 2007;24(3): 19.

9. Marushchak M, Krynytska I, Petrenko N, Klishch I. The determination of correlation linkages between level of reactive oxygen species, contents of neutrophiles and blood gas composition in experimental acute lung injury. Georgian Medical News. 2016;253: 98-103. Available at: https://www. ncbi.nlm.nih.gov/pubmed/27249444

10. Cardo D, Dennehy PH, Halverson P, Fishman N, Kohn M, Murphy CL, Whitley RJ, HAI Elimination White Paper Writing Group. Moving toward elimination of healthcareassociated infections: a call to action. Infection Control \& Hospital Epidemiology. 2010;31(11): 1101-5. Available at: https://www.ncbi.nlm.nih.gov/pubmed/20929300

11. Johanson WG, Dever LL. Nosocomial pneumonia. Intensive Care Medicine. 2003;29(1): 23-9. Available at: https://www.ncbi.nlm.nih.gov/pubmed/12528018

12. Bagheri-Nesami M, Amiri M. Nurses' knowledge of evidence-based guidelines for preventing ventilator-associated pneumonia in intensive care units. Journal of Nursing and Midwifery Sciences. 2014;1(1): 44-8.

Received 09.09.2019 